\title{
Cultural Identity Discourse Management By Riau Malay Elites
}

\author{
Alfarabi \\ Universitas Bengkulu \\ alfarabi@unib.ac.id \\ Anter Venus \\ Universitas Padjajaran \\ venusantar@yahoo.com
}

\author{
Nuryah Asri Syafirah \\ Universitas Padjajaran \\ asri_sjafirah@yahoo.co.id \\ Noor Efni Salam \\ Universitas Riau \\ efnisalam@gmail.com
}

\begin{abstract}
The strength of post-reformation Malay cultural identity is seen when the policy of regional autonomy and the electoral system directly meet with local elites who want to gain power. The way used is with the politics ethnic groups nomenclature. In practice, the group that is named by the elite sometimes does not know and does not speak. The situation illustrates how the Malay discourse has been dominated and hegemonized through narratives formed by the elite. This study aims to find out how the management of discourse to-Malays by the local elite in obtaining sympathy and support of the Malays in Pekanbaru Riau. The elite way of naming the interests of ethnic communities is examined in a representative political approach. Case study method is used to understand the dominance issue of Malay discourse by the elite used. The results of the field study resulted in the finding that the Malay elite embodied the discourse of cultural identity through a laskar organization that used the symbols of Malay identity and claimed to be the guardian of marwah. The desire of most people to restore the glory of Malay, processed by the elite as an instrument to get support and sympathetic. Ultimately, the support of the Malays is used by the elite to pressure local governments and companies in Riau to pay more attention to the welfare of Malays. The actions taken are communicated back to the community in an effort to maintain support. In a pragmatic form, this support is also used by the elite to take individual or group advantage. Especially on elites who have strong masses of support, their support can be used to run or support the candidate he wants in an election.
\end{abstract}

Keywords_identity; discourse; elite; malays; representation

\section{INTRODUCTION}

Discussing the existence of the elite is discussed the party having authority, and the existence of those who have authority will only be meaningful when faced with the party who has no authority. Elite as a ruling class has greater authority than the masses as a class or a controlled party [1, p. 139]. In this study the Riau Malay elite refers to individuals occupying certain positions in the local domain. An individual may attain and occupy that position if the person has the resources as a basis and is able to optimize it so that it in turn delivers it as a local elite. Power is acquired by the elite because of the resources possessed by a person or group, which can serve as a means or means to influence other people or groups as desired [2, p. 371].

Falling down of the New Order regime, the local political system of Riau experienced a change in which the Malay elite had wider space to express its presence and role in the region. This local political space has made the interests of the group more visible in life the people of Riau.

Based on the results of pre-research in the field, it was found that the Malay elite controlled the mainstream of communication in discouraging the issue of Malay identity. Issues managed by the Malay elite eventually became the reference of the people of Riau. The result of this study is in accordance with the study of Sjaf, Kolopaking, Pandjaitan, and Damanhuri [3, p. 175] which states that the actors who manifest in the form of elite society in the area of local political economy dominate more than the masses (dominated) by me (re) production of ethnic identity for economic and political interests.

The dominance of the Malay elite to the people of Riau is caused by the resources possessed by the elite that can be used as a tool or means to influence the community. One such resource is one's position and wealth. Those who have these resources are ultimately more likely to influence. The Malay Elite in the life of the people of Riau is positioned as a person or group that conveys something and is made reference by the community. This influencing process is also supported by Melayu characters who are more expressive than perceptions. The urge to express themselves to Malay society applies to various situations in both interpersonal communication, groups or other communication contexts [4, p. 34].

The strength of cultural identity in the era of regional autonomy is used by elites who want to gain power. The 
method used is political practice on behalf of ethnic communities. This encourages the political practice of representation by elites. Representation politics is an effort of the elite to gain profit by way of ethnic community identification. Ethnic identity restrictions are no longer used to strengthen identity, but are used for the benefit of the elite who represent them. The symbols of ethnic identity are used to gain legitimacy so as to hegemonize society.

The process of transferring ideas from the elite to the community can be interpreted as a communication process. The transfer of elite ideas supported by the community requires management to be accepted. From the description above, the researcher examines how the identity discourse management conducted by the Riau Melayu elite. The process of assessing the management of the discourse will provide an understanding of how society can be controlled by local elites.

\section{METHOD}

This research uses case study research approach. This study defines cases of ethnic identity discourse management by the Malay elite in Riau society. Case study researchers study the most recent ongoing real-life cases so they can gather accurate information without loss of time [5, p. 137].

\section{RESULT}

When the elite utilizes its ethnic community for their own sake, the instrument for gaining trust is by constructing that ethnic identity struggle is for the common good. The elite's way of acting on behalf of the ethnic community's interest as a way of benefiting individuals or groups is called representational politics.

The identity of Malay is first translated by the elite so that it becomes a reference for its ethnic community. The implication of this makes the meaning of Malay identity undergoing a translation process as desired and giving the elite an advantage. The existence of translation by the elite shows that there is a power relation that is being practiced. The translation process requires power to run in people's lives. This power can take the form of economic, social or genealogical power. The existence of power possessed by a handful of people in ethnic communities divides society into elites and common people. The practice of the elite that influences and determines the direction of most ordinary people is called domination. The existence of dominance makes the elite in working as if on behalf of the wider community.

\section{A. Stuttering Malay Degradation Identity Post Reformation}

Thirty-two years in the stranglehold of the New Order, the identity of Riau Malay was marginalized in its own country. These conditions make the new Malay discourse flourish postreform. Euphoria displays the identity of the Malay-is displayed in various symbols that make a person aware of their Malayness. Nevertheless, Malay as a new identity is recognized as a symbol in general but has not provided a strategy to strengthen the bargaining power of identity. There is a stir when ethnic identities are confronted with the conditions in which they have undergone many changes. The awareness of the ethnic identity present at the time of modernization has changed the Malay region with the mastery that is not held by the Malays themselves.

Riau Malay region is abounded by natural wealth of high economic value is so realized by the Riau Malay. Mining, especially petroleum is controlled by State companies and they do not know how the oil profits for Riau Malays. The forest area is also controlled by a company that manages thousands of hectares, leaving little for the Riau Malays themselves. This rich, controlled territory provokes the stutter that identity is not merely the symbols displayed.

The stuttering of Malays who are newly aware of ethnic identity in the midst of modernization progress requires a bridge connecting the two. This condition gives rise to people who give awareness that being Malay means also having Malay area where the wealth present in Malay region is for Malay prosperity. Those who do not provide welfare to the Malays means not supporting the progress of Malays.

The sentence to unite the Malays who are experiencing the consciousness of their ethnic identity is 'marwah'. The word marwah became unifier and realized by the elite so much used to move the Malay.

The Malay Elite presents the spirit of Identity in the form of Malay troops (laskar) who claim to be the guardians of marwah. The presence of these Malay toops gives its own color in the life of the community as it becomes one of the community's references even the local government. There were soldiers who emerged out of disillusionment with Malay Customary Institutions that were less progressive in their struggle for Malay fathers. Others are encouraged to promote Malay festivals in Pekanbaru and Riau in general. These troops are attached to Malay identity because they use the symbols of Malayness in the name of the group, the attributes, down to the issues being championed.

Troops who are considered to fight for the Malay marwah get a lot of sympathy so as to attract people to join. These conditions make the army-laskar have many members and scattered in Riau areas. The high interest of the community to join is shown through the management structure that is formed from the provincial level up to the village level. The organizer of Malay laskar center is located in Pekanbaru. Selection of Pekanbaru is caused by the factor that the elite of the army many settled in Pekanbaru which is the provincial capital. Factors of number of members and distribution throughout the territory of Riau become the forces of the army in negotiating with local governments and companies.

One of the heads of troop explained that the existence of the Malay troops gave them space to access large companies that had been dredging the natural wealth in Riau. The policy of a company that prefers to take workers from outside Riau the result of stereotypes that the Malayans are lazy and unwilling to work hard-can be intervened through the pressure of Malayan paramilitary troops. This Malay laskar action opens opportunities for Malays to work in the company. The result of pressure on the company has made the Malay people are no longer a spectator in the dredging of Riau's natural wealth.

Malay troop relations with companies in certain contexts ultimately lead to a mutual relationship. Companies that 
require labor will contact the elite of the army in the provision of resources, otherwise if there is a problem with workers then the company will also contact the elite of the army to help solve the problem. As long as the relationship remains good then both parties will support each other. If the relationship is not harmonious it will happen scramble (a disturbing action) in the form of demos or other action actions.

Melayu troops also put pressure on the local government to pay more attention to the Malay fathers. Governments are encouraged to create policies that display Malay's identity and welfare. Pressure on local government is delivered through statements in the media, direct discussion, or recommendation. One of these forms of attention is translated into a form of attention to the Malay laskar.

\section{B. Elite and Malay Discourse Management}

Stuttering post-build identity creates hope for the rise of Malay at this time. The term that emerges is "awakening a submerged stem". This term is a description of how the past glories are transferred to the present era. The cultivation of Malay as a highly cultured and wealthy region prompted hopes of returning to that era. To go back to the culture, it has been enhanced by bringing back the Malay symbols in the building (selembayung), clothing (belango bay), and the giving of adat titles. While the practice of ritual is carried out in every government events and rituals live like births and marriages that use Malay customs.

Different conditions are found in restoring the richness of wealthy Malay. The wealth of Malays in the form of crops such as forests and oil has been controlled by the State and the private sector. This situation has put the Malay community into a spectator in his own land. The desire of how to make Riau's Malay riches back to the Malays is managed by the Malay elite in lumping, uniting, and mobilizing Malays.

The Malay Elite uses discourse of Malayness to gain public support. The support of the Malays is used to bargain power both to local governments and to companies that control natural resources owned by Riau. Malay support in the elite can also be used as a mass movement in the form of action both to the government and the company. The existence of these actions is considered effective when elite pressure is not considered by local governments and companies.

\section{DISCUSSION}

Awareness of the desire of Malays to restore the glory of Malay processed by elite Malays to get support and sympathetic. Ability to process discourse Malay made messages that can be used to ignite the emotional identity in which the term marwah (identity) become the most efficacious spell. The pressure on identity in the new order era and the desire to restore the highly cultured and wealthy Malay marwah at this time made the energy of identity great and relatively quick to move.

The energy to inflict the submerged stems is channeled by the elite through the Malay discourses that attract the sympathy of Malays. This sympathy is ultimately used to gain support both in the attitude and actions of the Malays. Ultimately, the support of the Malays is used by the elite to pressure the local government and companies regarded as not paying attention to the welfare of Malays. This pressure can be in the form of statements and demo actions. In a pragmatic form these pressures can also be exploited by the elite to request job projects either to local governments or companies for the reason of financing Malay organizations and welfare.

Identity politics in the era of regional autonomy encourages the cultural identity to find its momentum on the people of Riau who had been marginalized. The old Malay sentiments were used by the ethnic elite to bind the emotions of the Riau Malay society through the disseminated discourse to strengthen their position in society. The ethnic identity of the situation has been politicized. The use of identity to attract public sympathy is a politicization process in gaining trust. To prove that Malay identity has been fought for, then Malay symbols are raised in buildings and clothing. However, the Malay people see it as not the main thing. To bring up the Malay identity Malay values should be a guide for Malays in thinking, behaving and behaving in everyday life. For that needed a role model that runs the values of Malays who breathe Islam.

\section{CONCLUSION}

Malay discourse managed by the Malay elite is the hope and dream of Malays in general. The dream is to restore the glory of Malay in the past. The return of Malay glory is desirable for the people in two fields. The first is the restoration of Malay culture in the land of Riau in the minds, attitudes and behavior of everyday Malays. Second is the return of Malay wealth in Riau land to the Malay people themselves. These two hopes are managed by the local elite to gain the sympathy and support of the community in the form of discourses of Malay identity. These Malay discourses are disseminated by displaying the brand of a person or institution that is positioned as an active subject who defends and fights for the rights of Malays. The condition was deliberately created to make differentiation with Malay figures who are considered not doing struggle for the Malays.

When the sympathy and support of the community are found, the Malay elite has strong bargaining power when faced with central government, local government and companies. The strong Malay elite's bargaining power can ultimately be used to exert pressure on parties deemed unconcerned with the interests of the elite.

\section{ACKNOWLEDGMENT}

The researcher expressed gratitude to Riau Malay figures who have helped provide an understanding of the research study.

\section{REFERENCES}

[1] Haryanto, "Elit Politik Lokal Dalam Perubahan Sistem Politik [Local Political Elites in Political System Change],” Jurn. Ilmu Sos. dan Ilmu Pol., 2009. [Online]. Available: https://www.journal.ugm.ac.id/jsp/article/view/10958.

[2] Y. Y. Prasetya, "Dinamika Internal Kekuasaan Antar Elite dalam Organisasi Pengurus Cabang Nahdlatul Ulama Kabupaten Lamongan [Internal Inter-Elites Dynamics in Nadhlatul Ulama Organization Branch 
of Lamongan Regency],” Jurn. Pol. Mud., vol. 3, no. 3, pp. 369-380, August-December 2014.

[3] S. Sjaf, L. M. Kolopaking, N. K. Pandjaitan, and D. S. Damanhuri, "Ethnic Identity Formationin Local Political Economic Arena," Sodality: Jurn. Sosiol. Pedes., vol. 6, no. 2, pp. 170-178, September 2012.
[4] A. Venus, Filsafat Komunikasi Orang Melayu [Malay People's Communication Philosophy]. Bandung: PT Remaja Rosdakarya, 2015.

[5] J. W. Creswell, Penelitian Kualitatif \& Desain Riset; Memilih di Antara Lima Pendekatan [Qualitative Research and Research Design; Choosing between the Five Approaches]. 3rd ed. Yogyakarta: Pustaka Pelajar, 2014 